\title{
Seeking Justice: Citizens' Use of Fair Hearings to Correct Errors in Public Welfare Bureaucracies
}

\author{
Vicki Lens \\ Columbia University School of Social Work
}

\begin{abstract}
An understudied area of public administration is administrative hearings, used by clients to challenge denials or reductions of aid in public welfare programs. They help ensure that officials are applying the law consistently, fairly and equitably, and as intended by policy makers. Drawing on 59 qualitative interviews with public assistance clients in an urban and suburban county in New York who received notices discontinuing or reducing their assistance, this study explores why clients appeal or not and their perceptions of hearings. The findings indicate that clients' decisions to contest agency decisions were influenced by their perceptions of how workers treated them, their reactions to powerlessness and stigma, and their social networks, especially client networks. Clients who filed appeals perceived hearings as a valuable tool, albeit one that needed improvements. Although concerned with outcomes, they also focused on the procedural fairness of the hearing and whether they had an opportunity to fully present their case to an impartial decision maker. Although some clients had difficulty navigating the appeals process, procedural fairness was possible to achieve, despite the evident power and status disparities between the parties.
\end{abstract}

An understudied area of public administration is administrative hearings, used by clients to challenge denials or reductions of aid in public welfare programs. Every major public welfare program, including the Temporary Assistance for Needy Families (TANF) program, Medicaid, and Social Security, uses administrative "fair hearings" to resolve disputes. Fair hearings are where citizens, often the very poor, make use of the legal machinery of government to challenge perceived mistakes. They help ensure that officials are applying the law consistently, fairly and equitably, and as intended by policy makers. They are a fixed feature of government, with states like New York holding over 80,000 hearings a year in its TANF program.

The passage of the Personal Responsibility Work Opportunity Reconciliation Act (PRWORA) has arguably increased the need for hearings. PRWORA, commonly referred to as welfare reform, imposes a 5-year lifetime limit on benefits and requires recipients to work in exchange for benefits. Recipients who do not comply with the work rules can

Special thanks to Kim Hopper and Journal of Public Administration Research \& Theory referees for their helpful comments. Address correspondence to the author at VL2012@columbia.edu. 
be sanctioned, temporarily losing all or a part of their grant. This has made welfare eligibility more complex, requiring often subjective and discretionary assessments of clients' work behaviors (Diller 2000). Denying assistance is often equated with encouraging self-sufficiency.

Much of the power to deny aid is held by front line workers. Because such enhanced discretion and power can lead to inconsistencies and inequities in service delivery, including errors of stringency, mechanisms for insuring worker accountability are essential (Diller 2000). Fair hearings are one such mechanism, as states are required "to provide opportunities for recipients who have been adversely affected to be heard in a state administrative proceeding" (42 U.S.C. Sec. 402). Hearings protect individual rights and access to welfare, thus balancing welfare's goals of ending dependency while supplying basic needs.

Hearings also serve an important normative function. If perceived as fair, hearings reinforce the legitimacy of governmental authority. They can convince clients of the appropriateness and correctness of the governments' actions even when no error has occurred (Super 2005). It also sends important messages about social inclusion and citizenship when government responds to complaints. This is especially relevant to welfare clients, whose social exclusion and second-class status is well documented (Handler 2003; Hasenfeld 2000; Seccombe 2006).

Little is known about clients' use of fair hearings as most empirical studies on the topic were conducted decades ago. These studies, primarily quantitative, found low appeal rates but high success rates. This project is part of a larger study, the first in many decades, to examine the fair hearing system. Using quantitative research methods, I first examined appeal rates and outcomes in three states, finding low appeal rates, except in New York City, but high success rates. I next conducted an exploratory qualitative study comparing appealers and non-appealers in Suffolk County, a suburban county in New York, where appeal rates are low. This study builds on that study and explores in greater depth the differences between appealers and non-appealers by comparing the two and by delving more deeply into the less typical and perhaps more interesting phenomenon of what motivates clients to assert their rights within the welfare center. Drawing on interviews with 59 clients from Suffolk County and New York City who received notices discontinuing or reducing their public assistance, I explore their decision to appeal or not and their experiences with fair hearings.

\section{THEORETICAL FRAMEWORK}

Welfare relationships are complex. Broadly, they are about the relationship between government and its citizens. Because these relationships occur within a bureaucracy, they are also about organizational behavior and how front line workers interact with clients. Because those clients are poor, they are also about powerlessness and stigma. Understanding when poor citizens choose to challenge government decisions that affect their basic needs thus requires many theoretical lenses. These include theories on how citizens evaluate the fairness of government institutions, what triggers individuals in general to file formal complaints, and how power or its absence affects people's willingness to complain, especially within public welfare bureaucracies.

Disputes are typically preceded by the perception a wrong has occurred, that something is unfair. There is a considerable body of literature that examines citizens' 
perceptions of fairness when interacting with government authorities (See for e.g., Lind, Tyler, and Huo 1997; Thibaut and Walker 1975; Tyler 2006; Tyler and Degoey 1995). Studies indicate that individuals distinguish between a fair outcome and a fair process (Tyler 2006). They are concerned both with how a decision is made and what the decision is. Both will influence their reaction to official decisions, with some, such as Tyler (2006), arguing that procedural fairness is more important to people than substantive fairness.

Substantive fairness means accurately and consistently applying the facts to a set of criteria (Galligan 1996). Procedural fairness is more subjective and includes individuals' perceptions of the decision maker and how they are treated. As Tyler (2006) found in his study of how citizens view police officers' decisions, citizens want an impartial decision maker who acts in good faith. They want their views considered and to be treated with politeness and respect. Civility is especially important; courteous and polite behavior signifies that the individual is of high social worth. Its opposite - rude or abrupt behaviorsignifies low social worth (Tyler 2006).

Welfare clients, like other citizens, are concerned with how they are treated as well as substantive outcomes. Welfare bureaucracies, as numerous studies indicate, are often harsh and unwelcoming (Bane and Ellwood 1994; Brodkin 1986; Gais et al. 2001; Hasenfeld 2000; Lurie and Riccucci 2003; Meyers, Glaser, and MacDonald 1998; Riccucci et al. 2004; Sandfort, Kalil, and Gottschalk 1999; Soss 2002). Welfare offices have been described as the least hospitable of government offices (Handler 1986; Hasenfeld 2000; Soss 2002). Its clients - single parents, usually female - are among the most stigmatized and powerless of social groups (Seccombe 2006). Interactions between workers and clients are often demeaning, authoritarian and punitive, and tinged with moral approbation (Hasenfeld 2000; Soss 2002). In such an environment, clients will likely find fault with their workers decision, whether that decision was correct or not. Perceptions of unfair treatment are likely to generate complaints.

When aggrieved, individuals may choose either to file a formal complaint or "lump it"; to exercise "voice" or "exit." One theory, labeled the "account model" by LloydBostock and Mulcahy (1996), views complaining as "social episodes" (458) about perceptions of unfair treatment. In their study of complaints made to the National Health Service in England about hospital care, they found that complaints often had social or nonmaterial goals. The primary motivation for pursuing a claim was to make transgressors account for a wrong and force them to acknowledge it. Consistent with Tyler's notion that procedural fairness matters, complainants sought to be understood and heard, even when the substantive outcome could not be changed.

Most of the scholarly literature on welfare bureaucracies (described below) focuses on why recipients do not complain. The few studies that explore why recipients do complain suggest the accounting model may apply. Cowan and Halliday (2003), in their study of the internal appeals process for homeless individuals in England who were denied housing, found that some clients appealed to call attention to their dissatisfaction with the bureaucracy and expose its wrongs. Similarly, Sarat (1990), in his qualitative interviews of welfare recipients at a legal aid office, found that recipients asserted their legal rights to render themselves and their needs more visible to the welfare agency. In the author's study of appealers and non-appealers noted above, some appealers wanted acknowledgment they had been wronged (Lens 2007). 
Other theories highlight the role of social networks in convincing people to file complaints (Mather and Yngvesson 1980-81; May and Stengel 1990). Outsiders to a dispute, including family, friends, or community groups, shape an individual's perception of being wronged and what to do about it. Similar to theories emphasizing social norms in shaping behavior, this literature suggests complaining is a fluid and socially reactive process influenced by others. The author's study cited above (Lens 2007) lends support to this theory. Virtually all of those who appealed, in contrast to those who had not, had been encouraged by social networks, including friends, families, fellow recipients, and community organizations.

However, as a multistate study of appeal rates and outcomes revealed, most clients do not appeal (Lens 2005). Appeal rates (except in New York City) are low, ranging from less than $1 \%$ in Texas and Wisconsin to $3.5 \%$ in the rest of New York State (Lens 2005). (In contrast appeal rates are as high as $21 \%$ in New York City.)

The most common explanation for why people do not complain, especially relevant to welfare recipients, is a lack of power. As Lukes (2005) explains, there are different dimensions of power. Sometimes the powerless will recognize a wrong but fail to act on it because of apathy, cynicism, or alienation. Other times they will be prevented from acting through force, threats, or manipulation. The most powerful form of powerlessness, according to Lukes, is an internalization of dominant beliefs and values that prevent grievances from even being named.

Thus, rather than responding to unfairness, powerless individuals may deny it exists. This may be particularly applicable to welfare recipients. They are often in psychological distress and stigmatized (Ensminger 1995; Goodban 1985). This may cause them to internalize blame when things go wrong. Because their expectations are low, recipients may perceive the denial of benefits as par for the course and hence not a challengeable wrong (Coates and Penrod 1980-81). Welfare reform, which eliminated the entitlement status of welfare and made benefits harder to maintain, may further dampen the perception of being wronged.

Even when a wrong is recognized, powerless people may still fail to complain. Welfare clients have a strong incentive not to antagonize workers who can deny basic needs and work-related resources (Diller 2000). Soss, in his qualitative study of 25 welfare recipients, found most unwilling to complain, believing it was better to "appear appreciative, respectful, and nonassertive in dealing with workers" (Soss 2002, 115). As Handler observes, since such relationships are ongoing, there is "considerable potential for at least the fear, if not the fact, of retaliation" (Handler 1986, 32). Skepticism may prevent complaining where fear does not, as this author found in her study contrasting appealer and nonappealers (Lens 2007). Clients who did not appeal viewed fair hearings, which take place within the welfare bureaucracy, as indistinguishable from an agency seen as inflexible and intractable and hence were skeptical of their usefulness.

Building on this earlier study I seek to more fully understand what motivates those clients who do appeal and how they differ from non-appealers. I explore both the decision to appeal and clients' experiences at fair hearings.

\section{RESEARCH DESIGN}

This current analysis is part of a larger study on fair hearing use in welfare bureaucracies. The first stage was a multistate analysis of appeal rates and outcomes, followed by 
a second study comparing appealers and non-appealers, both noted above. For the latter, I collected qualitative data and analyzed them using grounded theory, which is especially appropriate for new areas of inquiry and for exploring individuals' perceptions and experiences. I interviewed 34 clients in Suffolk County, a suburban county with low appeal rates similar to other counties and states. I found that the 14 non-appealers were often aware of mistakes and were not ignorant of their appeal rights but were skeptical of the usefulness of fair hearings. Those 20 clients who appealed had more favorable views of the appeals process and, unlike non-appealers, had social networks that encouraged them to appeal (Lens 2007). The purpose of the current study is to explore more fully the characteristics of complainers and how they differ from the non-appealers previously studied.

In the Suffolk County study, two groups of clients were interviewed: appealers and non-appealers. This study draws from the 34 clients interviewed in that study and 25 clients from New York City, for a total of 59 clients. New York City was chosen because appealers are more plentiful than in Suffolk County and most elsewhere. The inclusion of both a suburban and urban welfare system also permits comparisons of complaining behavior and fair hearing use in different geographical and organizational contexts. While Suffolk and New York City operate under the same state supervised fair hearing system and laws, the latter is a large urban bureaucracy, the former smaller, suburban, and less complex. As noted above, appeal rates are higher in New York City. Clients are also more likely to win; $81 \%$ of clients obtain relief after filing a fair hearing request compared to $43 \%$ in Suffolk County (Lens and Vorsanger 2005).

Since the Suffolk study included appealers and non-appealers, a wide array of agencies was used to recruit participants to capture a mix of assertive and more passive clients. Purposive sampling was used to locate clients who had received a notice denying, discontinuing, or reducing their assistance and who had, or had not, appealed the action. Sources for referrals included the county's primary legal services office for low-income clients and various social service agencies that provided housing, employment, and crisis intervention services. Referrals were also made by a nonprofit agency that assisted clients within the welfare agency. In New York City, the primary means of recruitment was through several community-based nonprofit advocacy agencies that would attract individuals asserting their rights. To broaden my sample beyond clients sophisticated enough to contact such organizations, I also recruited from a church-based soup kitchen likely to attract more vulnerable and less sophisticated clients.

Because there are many reasons for denials and reductions, initial field research focused on one type of reduction, work sanctions, to enhance the likelihood of specific themes and patterns emerging. During fieldwork, it became clear that clients' fair hearing use is fluid and complex; the same client who failed to appeal a sanction would readily appeal other adverse actions. Thus, the study was expanded to include other reasons for appealing, although work sanction cases predominated.

In Suffolk County, among the non-appealers, 36\% were African-American, 57\% white, and 7\% Hispanic. The average age was 32. Thirty-six percent had less than a high school education, 50\% had a high school degree, and 14\% attended at least some college. Fifty percent had received assistance for 3 years or more. By contrast, appealers in Suffolk County were more likely to be African-American, older, more educated, and spent more time on public assistance. Specifically, 50\% were African-American, $40 \%$ white, and 10\% Hispanic. The average age was 38. Twenty-five percent had less than a high school 
education, $60 \%$ had a high school degree, and $15 \%$ had attended at least some college. Sixty-five percent had received assistance for 3 years or more.

In New York City, where only appealers were studied, $72 \%$ of the clients were African-American, $8 \%$ white, and 20\% Hispanic. The average age was 45 . Thirty-two percent had less than a high school education, $24 \%$ had a high school degree, and $44 \%$ had attended at least some college. ${ }^{1}$ Eighty percent had received assistance for 3 years or more.

All but two of the Suffolk County participants were interviewed in their homes; the New York City participants were interviewed in the researcher's office. Interviews lasted approximately an hour and a half and clients were paid 25 dollars in Suffolk and thirty dollars in New York City. (The five-dollar difference covered transportation costs for New York City clients.) Interviews were conducted by myself and one research assistant in Suffolk County and two in New York City. All but one of the participants agreed to be tape-recorded. Clients were asked a series of open-ended questions that explored their general experiences with applying for and receiving welfare, incidents involving the reduction and discontinuance of aid, and for those who requested fair hearings, their perceptions, and experiences of the fair hearing system. Clients were also asked general questions about welfare reform and welfare policy.

Each interview (except the single interview that was not recorded and two interviews where the recorder malfunctioned) was transcribed verbatim. A grounded theory approach was used in data analysis. Grounded theory is particularly appropriate for studies, such as this one, that involve "learn(ing) from the participants how to understand a process or situation" (Morse and Richards 2002, 55; Strauss 1987). This approach reduces any preconceived biases, letting the data speak for themselves (Berg 1995).

Coding was conducted simultaneously with data collection and helped inform subsequent interviews. The researcher coded each transcript, with descriptive codes first attached to lines of data. Focused coding was then conducted, which involved identifying the most significant and/or frequent line-by-line codes and choosing codes that best categorized the emerging themes and patterns (Charmaz 2006). Coding was an iterative process, with the researcher returning to earlier coded transcripts to confirm, refute, or modify codes as they developed. The three major categories that emerged from the coding were "strategies and tactics for negotiating the bureaucracy," "nature of bureaucratic relationships," and "perceptions of the fair hearing experience." Examples of major codes that emerged under these categories included "failing to connect," defined as having a distant, nonexistent, unequal, or fractured relationship with an agency worker, "speaking up," defined as asserting an identity based on fighting for one's needs, and "wrestling control," defined as an attempt to exercise autonomy in an environment that restricts it.

Analytical memos were used throughout the process, first to define and describe various codes and then to conduct theoretical coding, which is a way of rebuilding coded data

1 Overall, in New York State, 34.4\% of TANF families are Hispanic, 20.8\% white, and 42.3\% African-American (US Department of Health and Human Services 2004). The lower percentage of whites in the New York City sample (8\%) and higher percentage of whites in the Suffolk sample (47\%) reflect demographic distinctions in the population between urban New York City and suburban Suffolk County. There were some differences between the sample and the national population in terms of age and education. For example, the average age of welfare recipients in the United States is 31, the average age in the sample was 40 (US Department of Health and Human Services 2004). Nationally, $46 \%$ of recipients have less than a high school education (US Department of Health and Human Services 2004). In the Suffolk and New York City sample, $29 \%$ and $32 \%$, respectively, had less than a high school education. Thus, the sample was older and more educated than the general welfare population. 
and establishing a conceptual framework by exploring the relationships between categories and subcategories (Charmaz 2006). I met periodically with research assistants to discuss the development of codes and compare and combine codes. Each transcript was coded by myself, and selected transcripts were coded by research assistants. Intercoder reliability of between $80 \%$ and $90 \%$ was obtained in those transcripts coded both by a research assistant and myself.

A limitation of this study is that it uses a relatively small sample size to explore two large and complex bureaucracies. Respondents also were not selected randomly but based on their use, or nonuse, of the fair hearing system after receiving an adverse notice and most typically a sanction notice. They represent a small sliver of the population that appeals. This study is also limited to describing the characteristics and attributes of appealers and nonappealers as they relate to environmental and institutional factors and not their psychological makeup, which may also influence their willingness to appeal. It also does not explore demographic differences in the appeal population, such as race. The methodology usedin-depth qualitative interviews - is appropriate for exploring understudied areas of research and to understand clients' experiences. But although this methodological approach is useful for developing, presenting, and expanding theoretical frameworks to a new population and new area of study, it is only a first, and not a final or full, glimpse of complaining behavior in welfare bureaucracies.

\section{FINDINGS AND DISCUSSION}

Disputes between clients and workers occur at any stage. They become formalized and subject to appeal when the agency issues an adverse notice denying, discontinuing, or reducing the client's grant. In the vast majority of cases, in both Suffolk and New York City, clients' grants were reduced because of a work sanction, typically the failure to attend a work-related activity, such as a Department of Labor appointment or training session. Thus, they did not involve complex disputes about clients' overall work behaviors but bureaucratic disputes over missed appointments. Other types of notices included discontinuances for failing to produce documents or attend appointments related to recertification. In a few cases, clients challenged the adequacy of their public assistance grants. Clients' decisions to contest these decisions were influenced by their perceptions of how workers treated them, their reactions to powerlessness, and stigma and by social networks, especially client networks.

\section{Evaluating the Fairness of Bureaucratic Decision Making}

How bureaucratic decisions are made are as significant as the decision itself. Citizens assess whether government officials are impartial and listen to them. Social niceties, such as politeness and respect, have symbolic meaning; they signal to citizens that their input is valued. If not given an opportunity to speak before a decision is made, citizens are less likely to view the decision as fair. Conversely, if they believe their views were considered, they are likely to view even unfavorable outcomes as fair (Tyler 2006).

A reoccurring theme in virtually every interview with clients in Suffolk and New York City, including appealers and non-appealers, was their perception they were not listened to. They described welfare relationships that were distant and fractured rather than personal and ongoing. Most could not respond readily with a name when asked about their 
caseworker. After being asked what he thought about his caseworker, Richard replied "I've been on this for over a year and if she was any good I would remember her name."2 Sarah jocularly stated "I don't even know if there's a lady by that name." Clients would sometimes resort to the generic and disembodied "they" rather than the personalized "he" or "she" when describing their welfare relationships, as when Steven complained, "It's like they have full control over you, full control over your children." (emphasis supplied)

This disconnect was by bureaucratic design; both New York City and Suffolk constructed systems shielding workers from clients and limiting access. Both made heavy use of receptionists for deflecting clients away from workers. Gaining access required persistence, as Alice described the process "you have to keep working, keep working to get to them." In Suffolk, most communication was in writing through "speedy requests." Clients who wanted to speak with their workers were asked to write their request on a written memo. They would then sit and wait in the reception area until they received a written response. These written interactions could go on for days and involve multiple speedy requests passed back and forth. In both counties, lines were busy and phone calls went unreturned. In Suffolk County, workers' direct phone lines were sometimes withheld from clients. As Paula summed it up, "it's really hard to get in contact with your caseworker, they act like they're the President."

Clients' perceptions of workers as faceless and unknowable were reinforced in their brief interactions with workers in both counties. As Mary explains, "they'll see you for all of a lousy five minutes. If they see you for ten minutes you're there for a long time." Meetings were described as rushed and impersonal and workers as harsh, cold, and lacking empathy. Denise explains, "it felt like a machinery, there was no humane contact. It was as if they tried to have minimal contact with you as they could ... they just want to deal with documentation." Susan echoed her description "They just let computers do the work." Carol explained "it was more like pushing papers and get out of the office." Mary stated "it's like you're a number."

Decision making was also dispersed, with other workers, such as Department of Labor employees and welfare to work contractors, deciding when clients had violated the work rules. Thus, although workers had considerable discretionary power over clients' cases, how decisions were made, and who made it, was often unclear to clients. Clients insistence that they did not know their worker's name was often more figurative than literal, symbolizing a generalized frustration and annoyance with an impenetrable bureaucracy. Its often Byzantine and immoveable nature made it difficult for clients to pin down who was at fault or responsible when things went wrong. Consequently, clients were unsure who to plead their case to or who would listen.

Clients also viewed the system as capricious and arbitrary and prone to error. Virtually every client interviewed in both counties thought their cases were handled incorrectly and complained of improperly applied work sanctions, incorrect budgets, or wrongful discontinuances based on misdirected notices. When pressed during the interviews to identify ways the agency had helped them, clients framed their examples as exceptions, as random acts of bureaucratic kindness rather than business as usual.

In short, clients in both counties appeared perpetually aggrieved. In their view, the essential elements of fair treatment were missing. The ability to present their views 
was cut short by a lack of contact or the brevity of their encounters with workers. Workers were perceived as the antithesis of impartial, making up their minds without access to sufficient information. Clients believed they could do little to influence their worker and secure better treatment. As Gerdy explained, talking to your worker was "like talking to the wind."

Despite their frustration with workers, clients did not personally blame them. Rather they depersonalized these relationships, attributing problems to the "system" or the vagaries of human behavior. Workers were rude or dismissive because they were having a "bad day," not because they personally disliked the client. Indeed, as several explained, welfare clients (although not themselves) were often a difficult bunch, thus it was not unreasonable for workers to treat them harshly. Workers were stressed, handling too many cases, or looking to evade work or pass the buck. But whether overworked or avoiding work, it was the system that created disgruntled workers.

Thus to clients, workers' impersonal and abrupt approach was emblematic of larger systemic problems. They judged the system as the sum of its parts, excusing their workers individual behavior, while concluding that overall the welfare bureaucracy did not give them a fair shake. Such a finding is consistent with the extensive literature cited above describing the negative bureaucratic environment of many welfare agencies. It was a perception shared by non-appealers and appealers alike; all described and experienced the welfare bureaucracy in similar ways.

\section{Choosing to Complain or Not}

Why do some clients choose not to appeal, whereas other equally as aggrieved clients do? As noted above, powerlessness is likely to suppress complaints, and most welfare recipients do not complain. "Getting along" is the more common response, with welfare clients, as depicted in the literature, acting strategically passive to avoid upsetting workers, who may retaliate against them for complaining (Soss 2002). Even if retaliation is not feared, skepticism may take its place.

The non-appealers in this study exhibited both fear and skepticism but mostly the latter. Some clients feared angering their workers; they did not want to "cause trouble" or "ruffle feathers." As Barbara explained, "if you get on their bad side" your benefits might be "cut off." But more commonly, even among the fearful, clients expressed resignation. As Shauna explained when asked why she did not appeal her sanction, "I just feel like it's just a waste ... I get frustrated ... it's just never gonna change." Or as Penny put it more bluntly, hearings were a "bunch of bullshit." Clients did not feel heard by their workers and, unlike their appealing counterparts described below, believed they would not be heard in the fair hearing room. They perceived their workers and hearings as indistinguishable and unbeatable. As Maureen explained, "you're not going to win against social services." Barbara believed "they all side together."

Thus, instead of challenging a system they perceived as unfair, they opted out. "Application fatigue" set in, with acquiescence the easier route. As Valerie explained, "I'm just too disgusted, just aggravated. So I didn't want to do it." Likewise Maureen explained she didn't appeal because "everything with them is a long and tedious process." Nor did such clients reach out to social networks or contacts that might have counteracted their ennui and alienation. When asked by the interviewer whether they had discussed the decision to appeal with others, virtually all the non-appealers reported they had not. As Mindy explained, 
“I don't really tell everybody I'm on social services." Some, like Penny, "never heard [about] anybody use[ing]" hearings and thus believed they were not worth the effort.

Appealers in both Suffolk County and New York City differed from their more passive counterparts in several ways. They were less fearful and dependent on workers, viewing workers as antagonists to be challenged rather than placated. They also managed the stigma and powerlessness of welfare by engaging and challenging the system, rather than acquiescing to it. Finally, they relied on social networks, often other clients, to support their decision to appeal.

\section{Redefining the Worker-Client Relationship}

Welfare relationships are relationships of dependency, with clients relying on workers to provide for basic needs. Such relationships are typically characterized by submissiveness and the fear that complaining would trigger retaliation (Handler 1986; Soss 2002). As noted above, the non-appealers in this study either did not want to rock the boat or did not feel it was worth rocking. In contrast, appealers redefined their relationships, seeing workers as someone who could hurt rather than help them. To such clients, complaining was a defensive maneuver that forestalled problems rather than creating them. As Diane explained, complaining prevented you from being "put through the system." Laura explained, "if you let them walk all over you that's what they're gonna do." Kate echoed her sentiments: "If you never speak up, you can never win."

To such clients, retaliation was not an issue, not being noticed or heard was. This attitude was best summed up by Paula who explained that complaining was a nothing to lose proposition: "what are they gonna do, call the cops on me? Or not help me that day? What are they gonna do? You know I really don't care. I mean they can't do much more than what they've already done." Complaining gave clients another bite of the apple or as Mara explained, "If I appeal ... I get more of a chance than just letting them say no." To these clients, dealing with the bureaucracy required assertiveness not acquiescence.

While complaining took many forms, from "talking back" to workers to climbing the bureaucratic hierarchy, clients turned to fair hearings when these approaches failed. Filing an appeal was also arguably the safest avenue because it did not require a personal confrontation with a worker. Sandy described fair hearings as a way to avoid an angry confrontation, and possible retaliation, from her worker: "There are times when you are so angry and frustrated that you want to lash out. But if you do anything disrespectful ... case closed by mistake. So if you don't know anything about a fair hearing or stuff like that you're screwed." Hearings acted as a safety valve for such clients, channeling their anger away for their worker.

For most clients, appealing was an act divorced from already tenuous relationships with workers; it was the proper bureaucratic response to being treated bureaucratically. A depersonalized bureaucracy, where blame was diffused and client worker interactions unstable or anonymous, created an environment conducive to filing formal complaints. Clients often expressed puzzlement when asked by the interviewer how their workers reacted to the appeal. Caught in a bureaucratic maze of red tape themselves, they assumed, correctly or not, their workers would not even know they had appealed. To clients, appeals had little to do with their worker. As Mara explained, "they don't have nothing else to do about it," once you appeal. Susan pointed out, "they still have their job" if you appeal, whereas Lettie explained, "I don't think that they'd even care if they knew." Fears of reprisal were dismissed; when asked if she feared retaliation for complaining Louise 
responded: "no, no, no, no, no, because they have the right to retaliate you could just do it too" (by reporting them to the Commissioners' office).

In several instances, it was the client's worker who advised appealing. Whether suggested to deflect clients' concerns or avoid confrontation, it confirmed the appropriateness of appealing and of viewing workers as adversaries. Other clients viewed workers as forcing them to appeal; had their workers been more accessible and attentive, they believed, the dispute could have been resolved. As Lloyd explained, it was his worker who "forc[ed] me to have a hearing, because I wasn't given a chance to explain to her." Similarly, Sharon explained, hearings were necessary because otherwise "they make a mistake and you pay for it." For Joyce, hearings "were the most immediate remedy that's gotten any result for me."

In short, clients saw their relationship with workers as not repairable. Unlike more passive clients, whose goal is to pacify their workers, they gave up on these relationships, viewing workers as apathetic or adversarial but not as allies. Instead of fearing them, they sought to override them. They viewed hearings as a second chance that protected them from workers they perceived as arbitrary. This occurred in both New York City and Suffolk County, thus suggesting that the nature and structure of relationships, and not necessarily the size or complexity of the organization, produce this effect in some clients.

\section{Managing Stigma and Powerlessness}

Appealers also differed in the way they managed welfare stigma and their own powerlessness. Instead of internalizing images of helplessness and incompetence, appealers projected outward, reciting a litany of the agency's mistakes rather than focusing on their own. In contrast to the more compliant and submissive noncomplainers, who, as described above, preferred laying low and disengaging from the welfare system, appealers constructed a conception of self with speaking up at its core.

This occurred in both counties, although clients from New York City stated it more forcefully. For example, Susan explained, "I'm the type of person that I just speak my mind ... I make it my business to put people in their place. So yes I do make complaints. I'll be on the phone with everyone from morning till the afternoon." Denise described herself as "relentless. That is the best description as to how to describe me. Relentless, when I felt like my rights were violated I could be relentless to defend myself." Louise, using the lingo of the market place, elevated herself from lowly welfare client to a customer, noting, "The customer is always right. You are supposed to service your client. Customer service is job one."

To reinforce the impression they were "fighters," clients accompanied these declarations with anecdotes of how they challenged their worker or corrected a mistake. Susan described how she got her worker to reverse the decision to send her to work after the birth of her child. Denise told a similar tale of being reassigned to another work assignment after strongly protesting her original one. Through such stories, clients depicted themselves as autonomous and capable individuals able to subvert embedded power hierarchies.

Thus, complaining served both instrumental and expressive purposes. It not only (sometimes) fixed the problem but also altered clients' perceptions of their marginality and vulnerability. Louise is one such example. She explained how she was first "hospitable" to workers, who were in turn "nasty" and "ignorant" and stereotyped her as lazy. She initially thought she was at fault: "I'm putting all the blame on myself" and then decides that while "they'll pretend it's you" it has little to do with her. She starts to complain 
after concluding, "You don't treat me like I treat you then, I'm gonna say something about it." Through complaining she reframed her experience, reproaching workers instead of herself.

Other clients made a similar connection between asserting their rights and affirming their dignity. Diane explained, "they feel you're less than because you are on social services. But I let them know I am somebody.” Richard said, “They don't show no respect at all. I mean, I demand mine, 'cause I let them know you know I put my pants on, or my shoes on the same way you put yours on, you know? And I'm not gonna tolerate you talking to me in the wrong way."

Clients also used their identity as complainers to distinguish themselves from other clients. They were quick to describe other clients as timid, ignorant, and fearful, whereas they were bold, demanding, and knowledgeable. Distancing oneself from fellow clients is a common tactic for managing stigma in welfare bureaucracies because it allows clients to reject negative stereotypes as inapplicable to them (Briar 1966; Soss 2005). Through such distinctions, clients affirm their normalcy and kinship with the non-welfare population (Soss 2005). By describing other clients as uneducated and unsophisticated in handling the bureaucracy, clients extend the social distance between them. Unlike other clients, they were more like the average citizen who knows how to negotiate with government.

As Lukes (2005) observes, powerlessness typically reinforces itself, breeding alienation, skepticism, and denial. It is more likely to produce the passive welfare recipient than the complaining one. Appealers broke this mold, attempting to subvert, rather than succumb, to power hierarchies. They projected a sense of agency, believing they could influence and alter agency decisions. Unlike their noncomplaining counterparts, they engaged the system. Paradoxically, although they spoke loudly and disparagingly of the system, they also had more faith that it could be changed. In short, they did not succumb to the ennui or alienation of the powerlessness; instead they chose agitation over apathy.

Appealing also served other purposes beyond correcting perceived wrongs. As LloydBostock and Mulcahy (1996) explain, complaining is sometimes best characterized as a "social episode" that can serve the noninstrumental purposes of "having been understood, taken seriously, and offered a satisfactory explanation (459)." A running theme throughout clients' talk was the desire to be heard, acknowledged, and respected, which they believed was withheld by distant workers and bureaucratic barriers. The format of hearings required the agency (and hearing officer) to listen to their complaints.

Lloyd-Bostock and Mulcahy (1996) note that complaining is also a way to expose perceived institutional wrongs and to call the agency to account. This form of complaining was illustrated by Sandy and Mandy. For Sandy, fair hearings allowed you to "tell about the system that is broken." Mandy made even more explicit the accountability function of hearings. She explained how she told her hearing officer "they have to investigate because they keep messing with people. You tell the people in Albany [the state capital where the stage agency is located] they need to send an investigator down here."

In sum, for appealers hearings served several purposes. It allowed them to see themselves as engaged, competent citizens able to play the bureaucracy's game. It gave them a platform from which to speak and be heard, to address problems of process, not just substance. Finally, in perhaps the penultimate act of overcoming the self-blame of the powerless, it allowed them to publicly finger the system as the culprit, rather than themselves. 


\section{Creating Complaint Networks}

Appealers also differed from non-appealers in their willingness to talk with others about their problems with welfare. As noted above, non-appealers in Suffolk County spoke about their decision to appeal with virtually no one. In contrast, appealers in both Suffolk County and New York City reported reaching out to social and professional networks. Clients reported multiple contacts with a wide range of networks, from politicians, to social workers, and to local community groups. These individuals and groups encouraged them to appeal and provided advice and support.

Some of clients' strongest networks were with other clients. Clients viewed one another as a lifeline, giving and receiving tips on surviving the welfare encounter. As Maureen describes

I actually learned more through friends of mine - if that's what you want to call them, they are friends of mine — who have been through the system, you know, you learn more that way than asking these people and trying to get a straight answer.

Sarah similarly describes her connections with other clients and how she helps them:

There's a lot of people down there that you have a camaraderie with even though you don't know them 'cause they're going through what you're going through. Like you'll go in there and when you walk out they're like, 'did you get it? Did you get it?' you know it's like, everybody's in the same boat, we all understand each other without even saying anything. I'll go to HEAP a lot 'cause I can't afford to pay my electric and my gas and, there'll be people down there, oh, you know 'how do you fill out this form' or whatever - and I'll tell them, you know 'this is what I've learned ... You give them little tips.

Paula describes herself as at the hub of a client network, the "go to" person when people have problems:

as soon as they have a problem the phone rings and, 'oh, what am I supposed to do with these people at social services, they told me that I can't get this.' Well they lied to you. You go back down there, you apply again, they have to help everybody no matter what.

Although such networks were more evident in New York City than Suffolk, they worked in similar ways. They were often instrumental in encouraging reticent, newer, or less knowledgeable clients to complain. Raymond, for example, described how a fellow client, who overheard his dispute with a worker who refused him emergency housing, advised him to request a fair hearing.

As Mather and Yngvesson (1980-81) emphasize, disputes happen in a social milieu. Other parties can influence how an individual responds to a perceived wrong, including whether a disputes is escalated or diffused. In this study, social networks, and in particular client networks, validated clients' complaints, while also helping clients overcome the skepticism and inertia that often beset powerless people in difficult bureaucratic environments. Other clients and outside networks served as a counterbalance to clients' oftencontentious relationships with workers, suggesting and validating some remedies, such as appealing, over others.

\section{Assessing the Fairness of Fair Hearings}

In contrast to client worker interactions where clients' concerns can be deflected, hearings are structured to provide clients with an opportunity to be heard in a neutral forum. Both the 
client and the agency appear in person, although the latter is not the caseworker that made the decision but an agency representative assigned full time to hearings. Both have an opportunity to present evidence and cross-examine witnesses. Hearings are presided over by a hearing officer designated by the state. A written decision is required.

As they did with their workers, clients looked for certain markers of fairness. They had firm notions of fairness, defining it as studies have found most citizens do: the opportunity to speak, have their views considered by an impartial decision maker acting in good faith, and to be treated with respect (Tyler 2006). As Lucy explained, in a "nutshell" fairness meant being "given the opportunity to say what I have to say and replying to me in a decent manner and treating me as a human being." In both their search for impartiality and an opportunity to present their case, hearings sometimes, but not always, fell short.

\section{Looking for Impartiality}

The relationship between the hearing unit and the local welfare office proved problematic to clients. Although the players were new (the agency representative and the hearing officer are unknown to the client), hearings stand within the welfare bureaucracy, not outside it. The relationship between the two is less distinct, for example, than between the police and the court system. The state welfare bureaucracy, who has supervisory responsibility over local offices and generates many of the rules clients are challenging, conducts hearings. Clients generally appear without an attorney, thus their experiences are unmediated by an outside third party. Hearings are thus a continuation of an existing bureaucratic relationship already characterized by low social status, powerlessness, and stigma. Although parity between parties in adversarial proceedings is never assured, welfare clients virtually always enter the hearing room in a subordinate and disadvantaged position and unsure of the impartiality of the hearing officer.

Clients were often unclear of the precise relationship between the hearing officer and the agency representative. Hence, they closely scrutinized these relationships for signs of partiality. Seemingly minor details, such as entering a room where the hearing officer and agency representative are already sitting, contributed to clients' doubts that the decision maker was neutral. The easy familiarity clients sensed between the hearing officer and agency representative, who worked together daily, also elicited distrust. As Lila explained

I'm coming in, and they're already in the room, they're already talking to each other and, they know each other, of course.

How can you tell?

They're calling each other by first names, they're laughing. I'm nervous, you know, I'm not in this atmosphere as they are. Honestly, I'm the enemy and they're the - they're friends.

OK, so when you walk in you feel that, from the start?

You feel the tension, yeah. And then when I come in, then they, 'alright, we're here on the case of Miss R., versus the Department of Soc'-you know and it's like, oh I know I'm gonna lose.

Along with impartiality, clients focused on the tone of the hearings, often connecting the two. As Tyler observes (2006), respect and politeness are central to perceptions of fairness. It "sends a message about one's standing in a social group" (Tyler 2006, 150), signaling one's worth and value as a citizen. Conversely, treating someone rudely and impolitely signifies social exclusion and low status. 
Clients' harshest encounters, in New York City and Suffolk, were typically with the agency representative, who often questioned them more aggressively than the hearing officer. Most clients described agency representatives pejoratively, using such terms as "rude", "callous", or "nasty." They felt demeaned by these interactions. As Denise explained, "they try and make me look stupid ... very accusatory and very disrespectful." Steven described how the agency representative "was trying to really just make me feel like I ain't trying to do nothing. You know, like I'm a drug addict ... that's how he made me feel. You, know because I know I don't have the nice clothes." Lucy complained that "they always looked angry" whereas Wendy said, they "treated her like a low life." To clients, the agency representative's harsh and unremitting adversarial style signaled disrespect. It replicated their treatment at the welfare center and eroded expectations that the hearing room would be different than the welfare office.

It also created doubts about the hearing officers' impartiality when he or she failed to alter the tone or, as one client put it, make sure that the agency representative was "professional, [and] mind[ed] [their]manners." Denise, who won her hearings, nevertheless described them as unfair because of her perception that the hearing officer was too passive. As she explained, the hearing officer "let HRA run you over. They step back ... it is like you watching somebody committing a crime and you say nothing, you just let it happen. They just sit there ... they playing passive, makes you feel like the judge is out to let them run over you and say nothing, you know." Alice echoed her complaint that the hearing officer was not really impartial because "they don't say much. They should say more. They should be, they should be the ones really like to ask the questions." To such clients, hearing officers ceded their authority as an impartial decision maker when they failed to restrain the agency representative.

As the above examples illustrate, the hearing officer's style and demeanor were of central concern to clients. When hearing officers played a more active role, clients were more likely to perceive their hearings as fair. By directing questions to both sides equally and respectfully, hearing officers reinforced their impartiality, and clients were more likely to conclude that the decision was based on the facts, and not the party's status. As Russ explained after describing a hearing with an active and attentive hearing officer, outcomes "depend on the case. You know, if I go in there, and like I'm going in there for nonsense, he's gonna back them up more ... If he sees that you're in the right and they actually did this wrong, they didn't follow their own rules, he'll go on your favor and he'll actually go down on them."

Impartial, polite, and respectful hearing officers generated trust in the process. They provided what Tyler (2006) calls a "cushion of support" against complaints of unfairness even when the outcomes were unfavorable (99). Clients were more likely to describe hearings as fair if these elements were present, even when they lost. Louise is one such example. As she explained "at least you can get a word in edgewise" [at hearings] and the hearing officer will "actually ask the agency a real question." Because she thought she was treated fairly and listened to, she accepted even her losses, explaining "you know everything is not gonna go your way all the time, you know you got the good as well as the bad." Jane also distinguished between substantive outcomes and the hearing process. Because her hearing officer actively questioned her and the agency representative, she concluded that even if she had lost her hearing, she thought it was fair.

In contrast, clients who described the hearing process as unfair had doubts about the hearing officer's neutrality. Some believed that hearings were for "show" and 
the decision preordained against the recipient. Connie is one such example. Her benefits were cut when an agency appointment conflicted with a postsurgical doctor's appointment. Told to keep her answers simple during the hearing, she concluded that the "judges mind was made up before [she] came in the room." She viewed the judge as an advocate for the state who wanted to "keep contributions in the state." She was convinced that there was a "quota of people" eligible for benefits and that she had "hit the quota." She did not see the hearing officer as neutral or impartial, in part because she did not, in her view, allow her enough time to speak. Others with similar complaints like Paula, believed "it was just all social services, there's nobody outside of social services." Gloria believed "they're just for the system that group works together and their job is not to give people money."

In sum, impartiality was a key concern of clients, as it is with most citizens when evaluating the fairness of legal authorities. But unlike other legal forums, the distinction between their adversary - the agency — and the decision maker was not always clear. Clients entered the hearing room suspicious of the hearing officer's impartiality. Whether hearing officers stuck to the legal formalities was less important than their tone, style, and demeanor. Clients were more apt to use the latter as markers of impartiality.

\section{Looking to be Heard}

Like most legal proceedings, hearings focus on evidence, in the form of written documents and oral testimony. How their evidence and testimony was treated influenced clients' perceptions of whether they had an opportunity to present their case. Both proved problematic for clients.

Clients commonly believed that their word was not equivalent to the agency's. As Alice explained, in a "he-said she said" rendition of what occurred, the agency was more apt to be believed. Kate concurred, "they usually go by the word of the other worker, and not you, unless you have the documentation ... they can have nothing either, but they'll take their word over yours, which I don't like."

Written evidence proved even more elusive for clients. The coin of the realm, both for the welfare bureaucracy and fair hearings, is written documents. As Miller and Holstein (1996) explain, documentation, or the reduction of every transaction into a written form, is standard fare for bureaucracies and take on a concrete reality even though they are a "partisan account" of events (9). The same is true for legal forums, which often rely on the written word to confirm the spoken. Several clients had an almost simple faith in the power of documents, especially when they were able to secure them. Lucy, nervous before her hearing, "look[ed] at the envelope" (proving she had received a notice of appointment late) to reassure herself and build her confidence. Similarly, Arlene knew "in her heart she would win" because "anybody in their right mind would see that it was not my fault" when she showed them that her recertification letter was sent to the wrong address.

However, for most clients, documentary evidence posed a challenge and put them at a structural disadvantage. The bureaucracy's business is to know about clients and to record what they know, establishing a documentary file that clients cannot duplicate or compete with. As Louise describes, echoing a common sentiment, "we're very ill-prepared when we go there ... they got a folder on us they know all about. Other than the notice- - what's on the notice-I don't have any particulars, or any supporting depositions, or any folder, or nothing." Debbie explained how clients are "bombarded, because they come out with all these papers, saying you haven't done this, you haven't done that, and you know, giving 
a breakdown of your history and you're so unprepared that you're like, oh my gosh, what am I to do?"

Clients paid close attention to how their evidence stocked up against the agency's and even how long the hearing officer looked at it. Louise was disturbed because "they didn't really look at my documents." As she explained "I took everything [the agency] gave for me to look at and read over, but why can't you look at what I'm trying to get you to see." Amy had a similar experience. While she won her hearing, she thought they just brushed [her evidence] to the side," and suggested that each person should have "the same amount of time to show their evidence." Connie was puzzled because the hearing officer returned her documents without copying them; as she explained "when he wasn't accepting the documentation that I had so that's when I . . f felt this is a lose-lose here." Such clients were sometime unaware of evidentiary rules and why some evidence was more relevant than others. However, accurately or not, and whether they won or lost their hearings, they perceived the application of such rules as denying them the opportunity to present their case and hence unfair.

Clients who thought their documentation was more thoroughly reviewed were more likely to describe their hearings as fair and impartial. Ned, who was sanctioned for not attending a work appointment, obtained a letter from the homeless shelter he resided in documenting mail delivery problems. When the hearing officer focused on the letter, Ned described him as "very business like. He did his job just like a judge." Richard also believed his documentary evidence (letters from physicians describing his disability) was carefully considered and describe his hearing similarly: "they're very honest in their decisions and fair in their decisions, they look at all the documentation, they listen to you, and based on the evidence you present them, I think they did a good job in evaluating the evidence, and they were appropriate."

Although most clients had a pragmatic approach to hearings, viewing it as a forum for correcting mistakes, some clients, mostly in Suffolk County, misconstrued the purpose of hearings. They viewed hearings as a forum for pleading an exception to the rules. They saw it as an opportunity to explain their unique and individual circumstances and were surprised when the hearing officer refused to set aside the law. As Paula explained, "it was just everything by the book" and the hearing officer was going to follow the rules "no matter what I said." Using the language of the law to criticize it, Sarah complained her "rights were totally violated" when the hearing officer simply explained the law (on Supplemental Security Income budgeting rules) and refused to change them for her. Other clients, in both counties, viewed hearings as a catchall for resolving all their complaints against the welfare department, thus misconstruing the linearity and specificity of the appeal system.

Over time, clients became more skilled at hearings. They learned the logic of the law and the difference between legal testimony and ordinary conversation. Relational accounts that emphasized social context and feelings gave way to more linear and limited explanations. As Conley and O'Barr (1990) have found, legal discourse is different than social discourse and may be particularly challenging for women, minorities, and the poor, who often rely on relational and expressive ways of talking. Several clients learned this lesson, and when asked what advice they would give clients at fair hearings, how to talk topped the list. As Arlene explained, it was important to "stay directly on subject and don't put anything personal into it." Amy, echoing her advice, said "Don't go in there like you hate the world." Acting "businesslike," Joyce explained, "puts you at their level, not beneath them." 
In sum, hearings were a mixed bag for clients. Inequities below were replicated in the hearing room, where clients perceived themselves as outmatched and overpowered, the odd man out among the repeat players, the hearing officers, and agency representatives who worked together daily. The forceful and domineering style of the agency representatives, cited by most clients, and the failure of hearing officers to sometimes restrain them, raised suspicions of unfairness. Although hearings were presented as a forum for scrutinizing the agency's decisions, in practice it was clients who often ended up scrutinized. Clients perceived commonly observed norms of politeness and respect, ritualized in other adversarial settings such as courtrooms, as sometimes lacking.

On the other hand, for several clients, hearings were their first opportunity to fully air their grievances to authorities. They were able to adapt to the legal systems demands, producing evidence and testimony to support their cases. Hearing officers who paid attention to such nonlegal factors as the tone and style of the questioning and whether clients were treated politely and courteously created environments perceived as fair by clients. As several clients' attested, procedural fairness was possible to achieve, despite the evident power and status disparities between the parties.

\section{IMPLICATIONS}

Hearings perform an important function within welfare bureaucracies. They not only correct agency error but also reveal organizational problems. Clients' perpetual state of grievance in both counties suggests that appealing served expressive as well as instrumental purposes. Clients appealed not only because of a perceived mistake but also, consistent with the accounting model of complaining noted above, to expose perceived wrongs to a larger audience. When bureaucratic interactions become routinized and impersonal, clients will seek other venues for relief and attention. Appeals are one such forum and serve as a substitute for the personalized attention lacking in worker client interactions. The value of personalized and individualized front line interactions, especially when implementing welfare reform's behavior-based changes, is well known (Bloom, Hill, and Riccio 2001). This study suggests it could also reduce appeals.

The findings also suggest specific changes for improving worker-client interactions. Clients perceived that the basic ingredients of fairness, including respect and an opportunity to be heard without prejudgment, were missing in their interactions with workers. Although some might contend that harsh treatment is necessary to motivate clients or deter them from welfare, a process perceived as fair would likely increase clients' cooperation and compliance. Fair treatment bolsters confidence in government, and citizens are more likely to comply and respect the law if authorities act evenly, in good faith, and courteously (Tyler 2006). This applies both in the hearing room and in everyday interactions with government officials.

This study describes a different type of welfare client than found in past research, which depicted welfare clients as unaware of mistakes and passive and fearful of retaliation from their caseworkers if they complain (Gilliom 2001; Handler 1986; Soss 2002). This study's findings suggest that some welfare clients can overcome what Lukes (2005) describes as the most insidious form of powerlessness: failing to even recognize a grievance. Instead of defining themselves as their workers did, clients learned over time, and often from each other, how to challenge the system, not passively acquiesce to it. To manage the stigma and psychological distress of being on welfare, they focused on the bureaucracies' 
errors, rather than their own, while also differentiating themselves from other clients who did not speak up for themselves.

Although this study focused on environmental and institutional factors and not demographics, it suggests some future areas of research for the latter. As noted above, appealers in Suffolk County were more likely than non-appealers to be African-American. New York City, which has the highest appeal rate in New York State, has a higher proportion of African-Americans than other counties in New York State (US Census Bureau 2000). Thus, further research is needed to explore the connection between ethnicity and appeal rates. Other demographic factors, such as education, age, and length of welfare use, also need to be explored.

Another question left unanswered by this study is why, given the bureaucratic environment, more clients do not appeal, especially in Suffolk County. Despite the difference in size and complexity of the bureaucracy, clients in Suffolk and New York City had similar bureaucratic experiences and similar explanations for what motivated their appeal. However, they had somewhat different experiences at their hearings. Although several clients were satisfied with their hearings in Suffolk County, they were also more likely to describe their hearings as unfair. Thus, they may hesitate to appeal again, as New York City clients often do. Overall, clients in Suffolk County_both appealers and non-appealers - were more skeptical of the system (Lens 2007). A probable reason for this skepticism is that Suffolk County clients are more likely to lose their hearings. As noted above, they are half as likely as New York City clients to obtain relief through fair hearings. Social networks and especially client networks, which influence decisions to appeal, are likely communicating this fact, thus resulting in fewer appeals.

The findings suggest some ways to improve fair hearings. Hearing officers could consciously and deliberately create a more inviting environment. Hearing officers set the tone and style of the hearing, with other actors taking their cue from them. Those who struck a balance between letting clients complain in their own way while keeping the hearing focused on relevant legal and factual issues created an atmosphere where clients felt heard. Hearing officers who actively asserted control over the agency representatives also created a more impartial atmosphere, with clients placed on a more equal footing with their adversary. Such clients were more likely to describe their hearings as fair, even when they lost.

Clients' inherent disadvantages in the hearing room also need to be addressed. Many had difficulty securing documentation from uncooperative bureaucracies and/or understanding the law. One potential solution is to redefine the role of the agency representative. Because they are repeat players with access to the law and bureaucratic files, they are by definition more powerful and knowledgeable than clients. It may be more effective to shift their role or have an additional agency representative act as a "friend of the court," rather than as an adversary, as other public benefit appeals systems have successfully done (Baldwin, Wikeley, and Young 1992). Agency representatives would be responsible for objectively seeking out information, including evidence favorable to the client, to assist the hearing officer in assessing the facts and law. Instead of an advocate with the goal of wining, their primary objective would be to ensure the agency acted properly. Requiring agency representatives to seek out favorable evidence would also lessen the inherent disadvantages clients bring to the hearing room. Such a redefinition of the agency representatives' role and responsibilities would likely enhance the procedural fairness of the hearings, invite fuller participation by clients, and improve the quality of decisions. In 
short, it would enhance one of the few tools at clients' disposal for correcting agency error, thus increasing accountability in public welfare agencies.

\section{FUNDING}

Lois and Samuel Silberman Fund of the New York Community Trust.

\section{REFERENCES}

Baldwin, John, Nicholas Wikeley, and Richard Young. 1992. Judging social security: The adjudication of claims for benefits in Britain. Oxford: Clarendon Press.

Bane, Mary Jo., and David T. Ellwood. 1994. Welfare realities: From rhetoric to reform. Cambridge: Harvard University Press.

Berg, Bruce. 1995. Qualitative research methods for the social sciences. Boston: Allyn \& Bacon.

Bloom, Howard S., Carol J. Hill, and James Riccio. 2001. Modeling the performance of Welfare-to-Work programs: The effects of program management and services, economic environment, and client characteristics. New York: Manpower Demonstration Research Corporation.

Briar, Scott. 1966. Welfare from below: Recipients' views of the public welfare system. California Law Review 54:370-85.

Brodkin, Evelyn. 1986. The false promise of administrative reform: Implementing Quality Control in welfare. Philadelphia, PA: Temple University Press.

Charmaz, Kathy. 2006. Constructing grounded theory: A practical guide through qualitative analysis. Thousand Oaks, CA: Sage.

Coates, Dan, and Steven Penrod. 1980-81. Social psychology and the emergence of disputes. Law \& Society Review 15:655-80.

Conley, John M., and William M. O'Barr. 1990. Rules versus relationships: The ethnography of legal discourse. Chicago: University of Chicago Press.

Cowan, David, and Simon Halliday. 2003. The appeal of internal review: Law, administrative justice and the (non-)emergence of disputes. Oxford, UK: Hart Publishing.

Diller, Matthew. 2000. The revolution in welfare administration: Rules, discretion, and entrepreneurial government. New York University Law Review 75:1121-220.

Ensminger, Margaret. 1995. Welfare and psychological distress: A longitudinal study of African American urban mothers. Journal of Health and Social Behavior 36:346-59.

Gais, Thomas L., Richard P. Nathan, Irene Lurie, and Thomas Kaplan. 2001. Implementation of the Personal Responsibility Act of 1996. In The new world of welfare, eds. R. Blank and R. Haskins, 35-64. Washington, DC: Brookings Institution Press.

Galligan, Denis James. 1996. Due process and fair procedures: A study of administrative procedures. Oxford: Clarendon Press.

Gilliom, John. 2001. Overseers of the poor: Surveillance, resistance, and the limits of privacy. Chicago: University of Chicago Press.

Goodban, Nancy. 1985. The psychological impact of being on welfare. Social Service Review 37:404-22.

Handler, Joel. 1986. The conditions of discretion: Autonomy, community, bureaucracy. New York: Russell Sage Foundation.

-2003. Myth and ceremony in Workfare: Rights, contracts and client satisfaction. Paper presented at 25th Annual Research Conference of the Association of Public Policy Analysis and Management, Washington, DC, November 7-9.

Hasenfeld, Yeheskel. 2000. Organizational forms as moral practices: The case of welfare departments. Social Service Review 74:329-51.

Lens, Vicki. 2005. Bureaucratic disentitlement: Are fair hearings the cure? Georgetown Journal on Poverty Law and Policy 12:13-54.

2007. Administrative justice in public welfare bureaucracies: When citizens (don't) complain. Administration \& Society 39:382-408. 
Lens, Vicki, and Susan Vorsanger. 2005. Complaining after claiming: Fair hearings after welfare reform. Social Service Review 79:430-53.

Lind, Allen, Tom Tyler, and Yuen Huo. 1997. Procedural context and culture: Variation in the antecedents of procedural justice judgments. Journal of Personality and Social Psychology 73:767-80.

Lloyd-Bostock, S., and L. Mulcahy. 1996. The social psychology of making and responding to hospital complaints: An account model of complaint behavior. In Oxford readings in socio-legal studies: A reader on administrative law, ed. D. J. Galligan, 438-65. New York: Oxford University Press.

Lukes, Steven. 2005. Power: A radical view. London: Palgrave.

Lurie, Irene, and Norma M. Riccucci. 2003. Changing the "culture" of welfare offices: From vision to the front lines. Administration \& Society 34:653-77.

Mather, Lynn, and Barbara Yngvesson. 1980-81. Language, audience, and the transformation of disputes. Law \& Society Review 15:775-821.

May, Marylynn L., and Daniel B. Stengel. 1990. Who sues their doctors? How patients handle medical grievances. Law \& Society Review 24:105-20.

Meyers, Marcia, Bonnie Glaser, and Karin MacDonald. 1998. On the front lines of welfare delivery: Are workers implementing policy reform? Journal of Policy Analysis and Management 17:1-22.

Miller, Gale, and James A. Holstein. 1996. Organizational contexts and dispute processing. The Sociological Quarterly 36:37-59.

Morse, Janice M., and Lyn Richards. 2002. Read me first for a user's guide to qualitative methods. Thousand Oaks, CA: Sage.

Riccucci, Norma M., Marcia K. Meyers, Irene Lurie, and Jun Seop Han. 2004. The implementation of welfare reform policy: The role of public managers in front line practices. Public Administration Review 64:438-48.

Sandfort, Jodi R., Ariel Kalil, and Julie A. Gottschalk. 1999. The mirror has two faces: Welfare clients and front-line workers view policy reforms. Journal of Poverty 3:71-91.

Sarat, Austin. 1990. "The law is all over": Power, resistance and the legal consciousness of the welfare poor. Yale Journal of Law \& Humanities 2:343-379.

Seccombe, Karen. 2006. So you think I drive a Cadillac? Welfare recipients' perspectives on the system and its reform. Boston, MA: Allyn and Bacon.

Soss, Joe. 2002. Unwanted claims: The politics of participation in the U.S. welfare system. Ann Arbor: The University of Michigan Press.

2005. Making clients and citizens: Welfare policy as a source of status, belief and action. In Deserving and entitled: Social constructions and public policy, ed., A. L. Schneider and H. M. Ingram, 291-330. Albany: State University of New York Press.

Strauss, Anselm. 1987. Qualitative analysis for social scientists. Cambridge: Cambridge University Press.

Super, David K. 2005. Are rights efficient? Challenging the managerial critique of individual rights. California Law Review 93:1051-142.

Thibaut, John W., and Laurens Walker. 1975. Procedural justice. Mahwah, NJ: Erlbaum.

Tyler, Tom. 2006. Why people obey the law. Princeton, NJ: Princeton University Press.

Tyler, Tom, and Peter Degoey. 1995. Collective restraint in social dilemmas: Procedural justice and social identification effects on support for authorities. Journal of Personality and Social Psychology 69:482-97.

US Census Bureau. 2000. Table 5. Population by race and Hispanic or Latino origin, for the 15 largest counties and incorporated places in New York. Washington, DC: Census 2000 Redistricting Data (P.L. 94-171) Summary File, Table PL 1.

US Department of Health and Human Services. 2004-2005. Table 8. Temporary Assistance for Needy Families-Active cases, percent distribution of TANF families by ethnicity/race. Washington, DC: US Department of Health and Human Services.

. 2004. Fiscal report on characteristics of TANF adults. Washington, DC: US Department of Health and Human Services. 